\title{
ANTONIO ALATORRE*
}

\section{Un soneto de Góngora}

unque es muy conocido este soneto, no estará de más releerlo:

Mientras por competir con tu cabello oro bruñido al sol relumbra en vano; mientras con menosprecio en medio el llano mira tu blanca frente el lilio bello; mientras a cada labio, por cogello, siguen más ojos que al clavel temprano, y mientras triunfa con desdén lozano del luciente cristal tu gentil cuello, goza cuello, cabello, labio y frente, antes que lo que fue en tu edad dorada oro, lilio, clavel, cristal luciente, no sólo en plata o víola troncada se vuelva, mas tú y ello juntamente en tierra, en humo, en polvo, en sombra, en nada.

Es, para mí, el mejor de los trece hermosos sonetos que Góngora compuso en 1582, a los veintiún años, cuando ejercitaba la mano y el ingenio para lo que haría después. El ejercicio consistió en buena medida en reelaborar modelos ilustres, para superarlos. Seis de esos trece sonetos son hispanización, modernización y "personalización" (asimilación al lenguaje poético que él se está fabricando) de sonetos italianos: uno de Sannazaro, dos de Torquato Tasso, otros dos de Bernardo Tasso y uno de Minturno. ${ }^{1}$ El soneto

* El Colegio de México y El Colegio Nacional.

${ }^{1}$ Sobre Góngora traductor o "trasladador" de poesía italiana he dicho algo en "Fama española de un soneto de Sannazaro", Nueva Rev. de Filol. Hisp., 36 (1988), págs. $966-972$. 
"Mientras por competir con tu cabello..." es reelaboración y superación del de Bernardo Tasso, "Mentre che l'aureo crin v'ondeggia intorno...", y también de uno de los más célebres de Garcilaso, "En tanto que de rosa y azucena ...", cuyo tema es idéntico. ${ }^{2}$

Ese tema, que bien puede llamarse eterno, fue particularmente productivo en el Renacimiento. Se le conoce con dos designaciones "técnicas": Carpe diem y Collige, vingo, rosas. La segunda, aunque menos frecuente, es de hecho la más adecuada. Procede del dístico final del Idyllium de rosis de Ausonio, poeta del siglo IV, muy leído en el XVI y en el XVII. ${ }^{3}$ Este Idilio de las rosas es lo que se llama "una joyita". En veinticinco dísticos muy musicales, que fluyen con artificiosa naturalidad, el poeta cuenta su paseo por un jardín de rosales, un día de primavera. Cada rosa es un prodigio (descripción minuciosa). iAh, pero con qué rapidez se deshojan! (descripción minuciosa también). Vale la pena leer una de sus reflexiones a través de las palabras de dos traductores-imitadores: ${ }^{4}$

Es la edad de las rosas sólo un día: su juventud y su vejez van juntas.

(Francisco Cascales)

\footnotetext{
${ }^{2}$ El modelo inmediato de Garcilaso fue asimismo B. Tasso: la botticelliana imagen de la cabellera suelta al viento ("... y en tanto que el cabello ... / el viento mueve, esparce y desordena") procede del verso "Mentre che l'aureo crin vondeggia intorno". (Sabido es que de B. Tasso tomó Garcilaso el esquema métrico de la "lira".)

${ }^{3}$ Claro que Ausonio nunca fue tan leído, admirado e imitado como Horacio, y este solo hecho podría explicar la mayor frecuencia de la designación Carpe diem, a pesar de que en la oda "A Leucónoe" (libro I, oda 11) no se dirige Horacio a una muchacha instándola a gozar de su juventud y belleza, sino a una fanática de la astrología, quizá vieja, que le ha estado dando lata al poeta con esas tonterías, y a quien él le contesta: 'No te metas en honduras; agarra el día de hoy (carpe diem) y deja en paz el día đe mañana'. Pero Carpe diem tiene la ventaja de la concisión; es una metáfora compacta que significa 'coge el día como quien corta el racimo maduro que la parra le ofrece' (carpere viene de la misma raíz indoeuropea que el griego karpos 'fruto'). El libro de Blanca González de Escanđón, Los temas del "Carpe diem" y la brevedad de la rosa en la poesia española [desde Juan de Mena hasta Ramón Pérez de Ayala], Barcelona, 1938, se refiere fundamentalmente a la influencia del Idyllium de rosis, no a la de la oda horaciana.

${ }^{4}$ Estas citas, y las que siguen inmediatamente, como también otras traducciones e imitaciones del Idilio de Ausonio, pueden verse en Marcelino Menéndez Pelayo, Bibliografta hispano-latina clásica, C.S.I.C., Santander, 1950, tomo 1, págs. 216-236.
} 


\title{
A florecer las rosas madrugaron y para envejecerse florecieron: cuna y sepulcro en un botón hallaron.
}

(Calderón)

\begin{abstract}
Al final, en un dístico, viene la repentina moraleja, tan "inmoral", tan pagana, desde el punto de vista cristiano:

Collige, virgo, rosas, dum flos novus et nova pubes, Et memor esto aevum sic properare tuum.

Coge, doncella, las purpúreas rosas en cuanto su flor nueva y frescor dura, y advierte que con alas presurosas vuelan ansí tus días y hermosura.

(fray Luis de León)

Coged el fruto con la breve vida, que la edad pasa y muda toda cosa y todo, al fin, tras sí lo lleva el tiempo.

(Cristóbal de Mesa)

Coge, pues, niña, coge prestamente la nueva y tierna flor, y considera que al mismo paso ha de pasar tu vida.
\end{abstract}

(Francisco Cascales)

Este paganismo ausoniano ${ }^{5}$ resoné en la poesía de nuestra lengua, por primera vez, en el ya mencionado soneto de Garcilaso:

... Coged de vuestra alegre primavera el dulce fruto, antes que el tiempo airado cubra dé nieve la hermosa cumbre.

\footnotetext{
${ }^{5}$ Ausonio, nacido en Burdeos, vivió en un Imperio romano cuya religión oficial era ya el cristianismo, pero sus alusiones a lo cristiano son protocolarias, cuando no frívolas. Su sensibilidad nunca dejó de ser pagana. Por lo demás, el curriculum de las escuelas todavía no se habia cristianizado, y Ausonio fue gramático de profesión, o sea maestro de literatura (latina y griega), naturalmente pagana. El cristianismo, para el, fue siempre un cuerpo extraño.
} 


\begin{abstract}
Marchitará la rosa el viento helado, todo lo mudará la edad ligera por no hacer mudanza en su costumbre.
\end{abstract}

Y el soneto de Garcilaso puede haber dispensado de la lectura del Idilio de las rosas a varias generaciones de poetas. La quintaesencia del Idilio estaba en el dístico final, y para elaborarla daba lo mismo acudir a Ausonio que a Garcilaso, o a Bernardo Tasso, o a eslabones posteriores de la larga cadena de poesías -sonetos sobre todoque asiduamente se escribieron en español sobre la efímera belleza de la rosa. ${ }^{6}$

El soneto de Góngora se inserta, desde luego, en esa cadena ('Goza, muchachita, tus encantos, antes que se marchiten'), pero a la vez constituye el inicio de una cadena distinta. Su materia poética es otra. Por principio de cuentas, en él falta nada menos que la rosa. Las imágenes de la hermosura son otras flores, el lilio y el clavel, y dos materias preciosas, el oro y el cristal. Y estos elementos están distribuidos con una simetría que en Garcilaso estaba apenas esbozada: "En tanto que [tu rostro es sonrosado] y en tanto que [tus cábellos son rubios]..." En Góngora hay cuatro mientras, uno para cada imagen. Por otra parte, la correspondencia entre tercetos y cuartetos es muchísimo más estricta en él que en Garcilaso. Y, sobre todo, la reflexión final de Garcilaso: que el tiempo ("la edad") jamás muda su costumbre de mudar todas las cosas 3 no puede compararse con el maravilloso verso final de Góngora. ${ }^{7}$

${ }^{6}$ La vasta recopilación de Juan Pérez de Gużmán; Cancionero de la rosa, Tello, Madrid, 1891-1892 (2 tomos, con un total de casi mil páginas), tiene muchas lagunas. Vale la pena recordar el final de "Señora doña Rosa, hermoso halago ...", donde Sor Juana dice: "... y advierta vuesarced, señora Rosa, / que le escribo nomás este soneto I porque todo poeta aquí se roza". O sea: 'no se me envanezca porque le dedico a usted un soneto; usted no me importa; lo que ocurre es que todo poeta tiene que pasar por esta prueba para demostrar su suficiencia'. (Aquí juega Sor Juana, pero no en sus otros dos sonetos de la rosa). El Ídilio entero de Ausonio no tuvo sino dos traducciones en los siglos de oro: la de Fernando de Herrera (en tercetos), incluida en sus Anotaciones a Garcilaso (Sevilla, 1580), y la del jesuita Antonio Bastidas (en silva), impresa en el Ramillete de varias flores poeticas de Jacinto de Evia (Madrid, 1676), y hecha seguramente en tierra americana (en Guayaquil).

${ }^{7}$ Herrera, gran elogiador de Garcilaso, al llegar en sus Anotaciones a "por no hacer mudanza en su costumbre", no puede menos que decir: "Éste lánguido i casi 
Esta simetría, esta artificiosa correspondencia de tercetos y cuartetos, este esquema "correlativo", con sus dos partes, la distribución y la recapitulación, si no invento de Góngora, tuvo ciertamente en él un difusor muy poderoso. ${ }^{8}$ Variantes del mismo esquema pueden verse en otros sonetos primerizos suyos, como "Tras la bermeja aurora el sol dorado...", "Raya, dorado sol, orna y colora..." (de 1582), y sobre todo "Ni en este monte, este aire ni este río..." (de 1583) y "iOh excelso muro, oh torres coronadas...!" (soneto "A Córdoba", de 1585). Prácticamente todos los sonetos correlativos que se escribieron en español son posteriores a 1585.

Vale la pena leer algunos de ellos, comenzando con dos de $L a$ Arcadia de Lope de Vega:

No queda más lustroso y cristalino por altas sierras el arroyo helado, ni está más negro el ébano labrado, ni más azul la flor del verde lino, más rubio el oro que de oriente vino, ni más puro, lascivo y regalado espira olor el ámbar estimado, ni está en la concha el carmesí más fino, que frente, cejas, ojos y cabellos, aliento y boca de mi ninfa bella, ángelica figura en vista humana; que, puesto que ella se parece a ellos, vivos están alli, muertos sin ella, cristal, ébano, lino, oro, ámbar, grana.

muerto verso, i mui plebeyo modo de hablar". Observación muy indicadora de los gustos exigentes que se estaban imponiendo en 1580, durante la mocedad de Góngora.

${ }^{8}$ Es obligada la mención de los estudios de Dámaso Alonso, "Versos plurimembres y poemas correlativos", Rev. de La Bibl, Archivo y Museo del Ayuntamiento de Madrid, 13 (1944),89-191; "Versos correlativos y retórica tradicional"; Rev. de FiloL. Española, 28 (1941), 139-153; y (con Carlos Bousoño) Seis calas en la expresión literaria española, Gredos, Madrid, 1951. El juego de ingenio está ya en epigramas griegos y latinos (de la antigüedad tardía y medievales): véase Ernst Robert Curtius, Literatura europea y Edad Media latina, trad. de M. Frenk y A. Alatorre, F.C.E., México, 1955, págs. 403-408. Quienes volvierón a ponerlo de moda fueron los poetas italianos del Cinquecento. 
Es un soneto casi perfecto desde el punto de vista estructural. $Y$ digo "casi" porque en el verso 1 cristal está adjetivado, porque en el verso 14 se lee grana en vez de carmesi, y porque lino no indica el color azul de los ojos de la ninfa bella: hay que entender flor de lino, como en el verso 4.

El otro soneto no sólo está hecho con más rigor en cuanto a la correspondencia entre el cuerpo del soneto y el final, sino que es mucho más rico en elementos:

Si la grana del labio Celia mueve, ámbar parece que su olor respira; cesa el jazmin, y allí la envidia admira las perlas que entre rosa y cristal llueve.

¿Qué vid en olmo o flor del sol se atreve a competir con lo que enlaza y mira? La voz es de ángel; la aura, si suspira, como azahar de abril su aliento bebe.

Puede ser sol, sile faltara al cielo, con una luz tan viva y amorosa, que el alma y los sentidos tiene en calma.

Finalmente, se ven cubrir de un velo grana, ámbar, jazmín, cristal y rosa, vid, flor, voz, aura, abril, sol, cielo, alma. ${ }^{9}$

Lo malo es que esa riqueza viene a ser bastante tramposa. La relación entre las perfecciones de la dama y los trece elementos acumulados en los dos últimos versos está muy emborronada. Lope, seguidor de todas las modas literarias-es imposible, al hablar de él, no reparar en su carácter "camaleónico"-, siempre confió demasiado en la facilidad de su pluma. Más que muestras de poesía bien acabada, esos dos sonetos son testimonio de que en 1598, cuando apareció La Arcadia, estaban haciendo furor los sonetos correlativos.

Muy parecido al segundo de los sonetos de Lope, y compuesto evidentemente poco después de 1598, es uno anónimo que comienza "Tu bella imagen de oro, Celia, miro...", y que acaba así:

${ }^{9}$ Lope de Vega, La Arcadia, en el tomo 38 de la Biblioteca de Autores Españoles, págs. 54 y 92 . 


\begin{abstract}
... Al fin en tu retrato engastó el cielo topacio, oro, zafir, concha, piropo, perla, nibi, cristal, plata y diamante. ${ }^{10}$
\end{abstract}

Manuel de Faría y Sousa (1590-1649), portugués establecido en Madrid, amigo de Lope y enemigo de Góngora, se propuso superar los dos sonetos de La Arcadia en uno que comienza "Dulce paz es mi amada en los amores, / y luz con que a sí, ciego, me encamina...", con diez elementos, distribuidos a lo largo de cuartetos y tercetos, que logran caber-ilos diez!-en las once silabas del verso final: "paz, luz, sal, bien, voz, fin, ser, par, sol, gloria". 11 Faría y Sousa era capaz de tours de force como el siguiente:

¿Procuras, pecador, pan provechoso?

¿Para perpetuarte paz procuras?

¿Pretendes por pastor primas pasturas?

¿Pides para pasar panal precioso?

¿Pecando por perverso palabrero

presumes pronunciar palabras puras?

¿Por palmas poseer, punir perjuras

pretensiones, presumes presuroso?

Pan puro, Paz perfecta, Pastor pío,

Panal, Palabra, Palma principales

previno pía penetrada palma,

paternal, preeminente Poderío, pregonado por plumas puntuales Pan, Paz, Pastor, Panal, Palabra, Palma. ${ }^{12}$

${ }^{10}$ Poética silva, manuscrito que fue de la biblioteca de Campomanes, según los extractos de Bartolomé José Gallardo, Ensayo de una biblioteca española de libros raros y curiosas, tomo 1, Madrid, 1863, col. 1086. Las composiciones de la Poética silva son de los últimos años del siglo XVI y primeros del.XVII.

${ }^{11}$ Manuel de Faría y Sousa, Divinas y humanas flores, Primera y segunda parte, Madrid, 1624, fol. 22 v. Los poetas italianos disponen de más ventajas en esta clase de juegos, pues les es lícito elidir la vocal final de las palabras y elaborar endecasílabos como éste: "fior', frond', erb', aria, antr', ond', arm', arch', ombr', aura".

${ }^{12}$ Manuel de Faría y Sousa, Fuente de Aganipe, Séptima parte (inédita). Mi fuente es Arthur L-F. Askins, "Manuel de Faría e Sousa's Fuente de Aganipe: the Unprinted Seventh Part", en Florilegium Hispanicum: Medieval and Renaissance Studies Presented to Dorothy Clotelle Clarke, Madison, Wisc., 1983, pág. 268. Lleva esta 
La parte VII de la Fuente de Aganipe, donde se encuentra este soneto, es la culminación de la carrera poética del extravagante Faría y Sousa. Todas las poesías de este libro son "de ingenio" (sonetos esdrújulos, agudos, de centones, en eco, retrógrados, distributivos; de paronomasias, etc.). Si nó hay un mínimo de simpatía o complicidad de parte del lector, todos esos versos están en el grado cero de la poesía (y aun por debajo de cero). Yo confieso que Faría me inspira la misma clase de curiosidad que los locos. Fue un maníaco compulsivo. Orgulloso de sus hazañas, en el prólogo de la parte VII las defiende combativamente contra los críticos mordedores, que nunca faltan: "iParécete, ioh presumido!, que todo esto es nada, y que nada es el presentarte aquí un tomo no pequeño que solamente consta destas fatigosas invenciones? ¿Murmuras lo no muy fácil de algunos versos o cláusulas? Obra otro tanto, y aun la mitad, y aun el diezmo, en la cuantía, y no te mejores en la sustancia, y preséntamelo; que yo te confesaré que has hecho mucho. Pero reconoce que no lo has de hacer, porque no puedes; y con eso callarás". Guardar todo el rigor en un soneto distributivo-recapitulativo no es cualquier cosa. Faría, que suele dar juicios sobre poemas ajenos, hubiera notado un desliz en el segundo de los sonetos de Lope que he copiado: la enumeración final altera el lugar que rosa y cristal tienen en el verso 4.

Veamos ahora este soneto de Paravicino, amigo de Góngora:

¿Viste, al romper la noche oscura, Fénix hermosa, el alba arrebolada? ¿bajar la nieve en copos rastrillada, desmintiendo a los ojos su blancura?

advertencia del poeta: "Paula de San Paulo, por estos nombres aficionada a la letra $P$, dio a glosar el verso último [con la] condición de que todas las palabras del soneto empezasen por $\mathrm{P}^{n}$ (lo cual parece excusa inventada para encubrir lo que tiene de frivolo y aun pueril semejante hazaña; $y$, en todo caso, ya en las citadas Divinas $y$ humanas flores de 1624 , fol. 24v, hay un soneto en P, "iPuedo pediros, Padre poderoso...?", con la misma enumeración final). Cf. este pasaje de la famosa epístola de Juan de la Cueva sobre la ciudad de México: "Seis cosas excelentes en belleza / hallo, escritas con C, que son notables: / [...] casas, calles; caballos admirables, / cames, cabellos y criaturas bellas" (Alfonso Méndez Plancarte,Poetasnovohispanos, tomo 1, México, 1942, págs. 13-14). León María Carbonero, Esfuerzos del ingenio literario, Madrid, 1890, incluye los juegos de este tipo en el capítulo dedicado al "lipograma", págs. 275-305. 


¿Has visto del naranjo la flor pura
en sutiles aromas destilada?
¿la blanca rosa en leche deshojada,
y de la tersa plata la lisura?
Pues si esta hermosa variedad te admira,
que arrojada en mil partes dulcemente
la omnipotencia a su Hacedor retrata,
¿qué hará el que en tu hermoso rostro mira
labios, cuello, mejillas, ojos, frente,
alba, nieve, azahar, rosas y plata?

La idea se parece mucho a la del primero de los sonetos de Lope: en el bello rostro se compendian (y mejoran) las bellezas esparcidas por el mundo natural. Los cinco elementos del verso 14 de Paravicino están, canónicamente, en el orden en que fueron apareciendo en los cuartetos, pero los cinco elementos del verso 13 están dislocados: a 1 alba, 2 nieve, 3 azahar, 4 rosas y 5 plata debiera corresponder 1 ojos (por su luz), 2 cuello, 3 labios (por el aliento), 4 mejillas y 5 frente, y no 3-2-4-1-5, como se lee en el soneto. También es poco rigor haber puesto flor del naranjo en el verso 5 , en vez de azahar. Ciertamente así habría razonado Faría y Sousa. Pero es claro que Paravicino (extraño fraile, tan sensual y tan artista) sabía muy bien hasta dónde llevar la obediencia a las "reglas" y de qué manera romper el rigor matemático en beneficio de la belleza.

Para volver a "Mientras por competir con tu cabello...", es fácil ver cómo ya Góngora había flexibilizado las leyes de la correlación. En el verso 11, oro, lilio, clavel y cristal guardan escrupulosamente el orden que tienen en los cuartetos, pero las correspondencias del

${ }^{13}$ Obras póstumas, divinas y humanas, de don Félix [Paravicino] de Arteaga, Alcalá, 1650 , fol. 89v. Este soneto debe de haberse escrito hacia 1620 . De la misma época es otro, anónimo, publicado en Revue Hispanique, 40 (1917), pág. 82: "¿Has visto al sol nacer por el oriente...?" La estructura es muy parecida; pero aquí las preguntas se prolongan hasta el último terceto, de manera que la recapitulación se hace en un estrambote: "Luna, iris, sol dorado, / nácar, cielo, arrebol, perla, oro, estrellas, / comparadas a ti no son tan bellas". Cf. el soneto "A Silvia" de Anastasio de Ochoa, curiosa imitación tardía de esta clase de sonetos (Poesías de un mexicano, Nueva York, 1828, tomo 1, pág. 88): aparecen sol, ámbar, nieve, perlas, diamantes y rosa, y el final dice: "... que a copiarte no alcanza nieve pura, / perlas, diamantes, sol, ámbar ni rosa." 
verso 9 "debieron" haber sido cabello, frente, labio y cuello en vez de cuello, cabello, labio y frente. Además, el verso 13 se refiere sólo a oro y a lilio -en la vejez, el cabello rubio se volverá blanco como la plata, y la frente inmaculada y tersa se volverá amarilla y ajada como una viola cortada de su tallo-, ${ }^{14}$ correspondencia incompleta, que deja fuera las parejas clavel-labio y cristal-cuello. Y donde más notoriamente se infringen las reglas es en el verso 14 , cuyos elementos no corresponden a los del cuerpo del soneto (en primer lugar porque son cinco y no cuatro).

Al verso 14 va a estar dedicado todo el resto del presente artículo. Es el "peor" desde el punto de vista de las reglas de la distribución y recapitulación (o recolección), pues quiebra la simetría tan bien guardada hasta ese momento; pero desde el punto de vista poético es sin duda el "mejor". Es un verso sorprendente, y la sorpresa consiste justamente en su asimetría. El lento desfile -en tierra, en humo, en polvo, en sombra, en nada-es, además, absolutamente fiel a la "moraleja" del Collige, virgo, rosas: 'Goza la vida, niña, antes que tú y ello (ello, toda esa belleza tuya) se convierta en nada'.

iQué "hallazgo", ese verso 14! Tal es el comentario que se impone; tal es el comentario que a lo largo de siglos han hecho los lectores de poesía. Claro que no surgió de la nada. No es imposible que Góngora se haya "inspirado" en el verso

\section{Ceniza, tierra, polvo, viento, humo}

de un soneto que por esos años corría en letra de molde. ${ }^{15}$ Se trata de un soneto devoto, de tono muy ascético. "Ceniza, tierra, polvo, viento, humo, [eso soy yo en la presencia de Dios]", dice su segundo

\footnotetext{
${ }^{14}$ Para el lector moderno, la palabra viola constituye un pequeño tropiezo. Es un latinismo crudo. Horacio compara la palidez de los amantes de Lice con el color de la viola (Odas, III, 10). Garcilaso lo imita en la canción V: el infeliz Galeota, perdidamente enamorado de Violante Sanseverino, se ha puesto amarillo como viola (tiene, siquiera así, algo de Violante). Y cuanđo Góngora, en el romance "En un pastoral albergue ...", dice que la muerte "va violando" el color de las rasas, lo que quiere decir es que Medoro, desangrándose, se está poniendo pálido como viola. Esa viola latina es el alhelí amarillo.

${ }^{15}$ Figura en Michel Darbord, La poesie religieuse espagnole des Rois Catholiques a Philippe II, París, 1965, pág. 303; Darbord lo toma de Marcelo Macías y Garcia, Poetas religiosos..., Coruña, 1890; y éste, a su vez, de un manuscrito fechado en 1555
} 
cuarteto. Es difícil imaginar al joven Góngora leyendo poesía piadosa, pero, si acaso conoció ese soneto, no es poco "hallazgo" el haber aprovechado la potencialidad de la tétrica enumeración poniéndola, no como comienzo de cuarteto, sino como verso final. ${ }^{16}$ Este verso proyecta su magia sobre el soneto todo, lo deja marcado con su sello, convirtiéndolo en muestra perfecta de "agudeza sentenciosa", según el árbitro de la estética barroca (Gracián, Agudeza $y$ arte de ingenio, discurso XXIX). De la felicidad de ese innovador verso 14 da testimonio el largo desfile de poetas que lo imitaron para dar contundencia y énfasis a toda clase de situaciones y de estados de ánimo.

El desfile se inicia, paradójicamente, con una ostentosa imitación de "Mientras por competir con tu cabello..." que de manera asimismo ostentosa evita el final que le dio Góngora. Los dos cuartetos y el primer terceto son un verdadero plagio (con cambios mínimos: "...mientras a cada labio, por cogello, / siguen más ojos que al clavel temprano; / mientras tu hermosa, larga y blanca mano/ en competencia da parias al cuello..."), pero el último terceto, de manera inesperada, dice así:

...porque, la flor de juventud pasada, el que alabare la vejez, o miente, o es falto de juicio si le agrada.

(el "Cancionero" del cuasi-mexicano Cristóbal Cabrera). Pero ese manuscrito, que se conservaba en la biblioteca municipal de Gijón -y que se perdió durante la guerra civil de 1936-39- nunca fue debidamente estudiado. La fecha 1555 no parece válida para todo el volumen, algunas de cuyas poesías son más bien de la época del Cancionero general de la doctrina cristiana de Francisco López de Ubeda (editado por primera vez en 1579, en Alcalá). Para más detalles puede verse Elisa Ruiz, "Cristóbal Cabrera, apóstol grafómano", Cuadernos de Filologia Clasica, Madrid, 12 (1977), p. 118. Cf. también mi "De poética hispano-portuguesa", Boletim de Filologia de la Universidad de Lisboa, 29 (1984), pág. 266, nota 33.

16 Tal vez pudiera tomarse en cuenta el verso final del soneto "iOh cortesía, oh dulce acatamiento...!" de fray Luis de León (el enamorado se dirige a la dama): "...cuando de vos se viere desterrado, / iay!, iqué le quedará sino recelo, / y nochey amargor y llanto y muerte?" Y puede haber confluido un verso de Camoens, tan admirado por el joven Góngora (habla Adamastor con Tetis): " $O$ ninfa, a mais formosa do Oceano, / ... / que te custava ter-me neste engano, / ou fasse monte, nuvem, sontho ou nada? ..." (Os Lusiadas, canto V, octava 57). 
Este soneto es obra del sargento mayor Antonio Vázquez, amigo del poeta Andrés Rey de Artieda, quien lo incorporó a un libro suyo impreso en $1605,{ }^{17}$ o sea el mismo año en que el soneto de Góngora tuvo su "editio princeps" en las Flores de poetas ilustres de España recopiladas por Pedro Espinosa.

En cambio Cervantes, amigo a su vez de Rey de Artieda y coetáneo suyo, termina así el soneto-epitafio "del Burlador, académico argamasillesco, a Sancho Panza" (penúltima página de la Primera parte del Quijote, impresa asimismo en 1605):

...iOh vanas esperanzas de la gente! iCómo pasáis con prometer descanso, y al fin paráis en sombra, en humo, en sueño!

En lo cual debemos guardarnos de ver una argamasillesca ridiculización de Góngora (hay muchas y claras señales de que Cervantes lo admiraba). La ironía cervantina es siempre compleja. En esos tres versos hay, trabado con la parodia, un inequívoco acento personal, autobiográfico. Y algo parecido ocurre en el capítulo 53 de la Segunda parte del Quijote (1615), allí donde le quitan a Sancho el gobierno de la Insula. Al comienzo transcribe Cervantes la solemne parrafada de Cide Hamete: "Pensar que en esta vida las cosas della han de durar siempre en un estado, es pensar en lo escusado...", etc.; pero inmediatamente acude en auxilio del lector: todo eso "nuestro autor lo dice por la presteza con que se acabó, se consumió, se deshizo, se fue como en sombra y humo el gobierno de Sancho".

Poco tiempo después de publicada la Primera parte del Quijote, el pintor-poeta Francisco Pacheco le escribía al poeta-pintor Juan de Jáuregui una epístola en que hay, como prologuito a la consabida descripción de la caducidad de la rosa, estos versos:

${ }^{17}$ Discursos, epistolas y epigramas de Artemidoro [nombre poético de Andrés Rey de Artieda], Zaragoza, 1605; ed. de Antonio Vilanova, Selecciones Bibliofilas, Barcelona, 1955, págs. 220-221. De hecho, también evita ese final el primer imitador de "Mientras por competir con tu cabello ...", o sea el propio Góngora en su șoneto "Ilustre y hermosísima María ...", de 1583. Pero es claro que él no podía repetirse. La enumeración final de este segundo soneto está hecha de elementos de signo positivo: "... antes que loque hoy es rubio tesoro/venza a la blanca nieve su blancura, I goza, goza el color, la luz, el oro". 


\begin{abstract}
iCuán frágil eres, hermosura humana! Tu gloria en esplendor es cuanto dura breve sueño, vil humo, sombra vana... ${ }^{18}$
\end{abstract}

Es evidente que Pacheco, al escribir esto, tenía presente el verso final del soneto de Cervantes (no el gongorino): las imágenes son las mismas: sombra, humo, sueño.

Lope de Vega, que admiraba a Góngora en la misma medida en que lo envidiaba, imitó por lo menos dos veces el verso famoso: primero en la Canción a la muerte de su hijo Carlos Félix (1613), donde aparece casi disimuladamente, en mitad de una invocación a Dios, como simple aposición de "nuestra bajeza":

...No repugne jamás nuestrà bajeza, sueño de sombra, polvo, viento y humo, a lo que Vos queréis, que podéis tanto..., 19

y años después como verso final de un soneto distributivo-recapitulativo (no muy estricto) de la comedia La discreta venganza:

...Mudanza ya, que no mujer, se nombre, pues cuando más segura, quien la tiene, tiene polvo, humo, nada, viento y sombra. ${ }^{20}$

También el antigongorino Faría y Sousa se vio obligado a imitar el famoso verso para rematar un soneto -"Esto, que pronta la razón

\footnotetext{
${ }^{18}$ De la epístola a Jáuregui no se conocen, según creo, sino los cuatro tercetos que el propio autor cita en su famoso Arte de la pintura. "Hurtaré estos versos-dicede una epístola que envié a đon Juan đe Jáuregui estando [éste] en Roma, y pasen por variedad y por pintura". (No sé cuánto tiempo estuvo Jáuregui en Italia, pero consta que en 1611 estaba ya en España). No hay mejor imagen del "desengaño", dice Pacheco en el último de los tercetos, que una flor "que abre, cae, seca el sol, el viento, el hielo". La cita procede del tomo 23 de la Bibl. de Aut. Esp., pág. 370.

${ }^{19}$ Lope de Vega, Obras poéticas, ed. de José Manuel Blecua, Planeta, Barcelona, 1983, pág. 486.

${ }^{20}$ Poestas lfricas de Lope, ed. đe José F. Montesinos, Clásicos Castellanos, Madrid, tomo 1, ed. de 1968, pág. 188. Según S.G. Morley y C. Bruerton, Cronología de las comedias de Lope de Vega, Gredos, Madrid, 1968, la fecha de La discreta venganza es "probablemente 1620".
} 
advierte..." - sobre el famoso episodio de la "conversión" de San Francisco de Borja:

¿Esto es frente que ha sido coronada?

¿Esto fue mano de jazmín vestida?

iOh vida! ioh sueño! ioh sombra! ioh punto! ioh nada! ${ }^{21}$

Juan Pérez de Montalbán, uno de los más fieles discípulos de Lope, adaptó el verso de Góngora para aplicarlo a los estragos causados por una erupción del Vesubio en la región de Campania; pero lo puso al comienzo:

Ya es humo, polvo, sombra, incendio, lodo esa de frutos selva organizada ...22

Pedro Soto de Rojas, imitador de Góngora -y del Góngora intrincado-, diluyó aún más el verso, pero lo reintegró a su sitio original, en un soneto dirigido a Miguel Colodrero de Villalobos ("Bizarro joven, cuya ardiente lira..."). En los cuartetos pone por las nubes los versos de su joven amigo. $\mathrm{Y}$ los tercetos dicen:

Los términos usurpe al ocio rudo, letargo del sentido halagueño, tu voz, al fatal golpe fuerte escudo.

Los trípodas desgaje al rubio Isleño, despoje a Anteo Hércules desnudo: que cuanto no es virtud, es sombra, es sueño. 23

\footnotetext{
${ }^{21}$ Faría y Sousa, Fuente de Aganipe, Primera parte, ed. cit., fol. 111v. El bogotano Pedro de Solís y Valenzuela (muerto en 1711) cita entero este soneto en El desierto prodigioso y prodigio del desierto, obra de tono profundamente ascético (ed. de $\mathbf{R}$. Páez Patifio, Instituto Caro y Cuervo, Bogotá, 1977, tomo 1, págs. 107-108).

${ }^{22}$ Es una de las muchas poesías laudatorias que figuran al final de la disertación del Dr. Juan de Quiñones sobre una reciente erupción del famoso volcán: El monte Vesuvio, ahora la montaña de Soma, Madrid, 1632. Puede verse una descripción de este libro en el citado Ensayo de Gallardo, tomo 4, col.11. El soneto fue reproducido por G.W. Bacon en Revue Hispanique, 25 (1911), pág. 460.

${ }^{23}$ Obras de don Pedro Soto de Rojas, ed. de Antonio Gallego Morell, C.S.I.C., Madrid, 1950, pág. 501. Por si acaso algún lector se pregunta qué está diciendo Soto de Rojas en estos endiablados tercetos (los cuartetos son bastante más claros), le diré cómo los entiendo yo: 'De la voz del poeta, que acaricia dulcemente los oídos
} 
Quevedo diluyó también el verso de su archienemigo Góngora en el primer cuarteto de uno de sus sonetos "metafísicos", ponderación de la brevedad de la vida:

Fue sueño ayer; mañana será tierra; poco antes, nada; y poco después, humo: iy destino ambiciones, y presumo, apenas punto, al cerco que me cierra!...,

cuyo verso final es ciertamente contundente, pero con otra clase de contundencia, muy quevedesca: las horas y los momentos que pasan son azadas que "cavan en mi vivir mi monumento". ${ }^{24}$

En cambio, el portugués Francisco Manuel de Melo (1608-1666), admirador y amigo de Quevedo, no sólo reproduce íntegramente el verso de Góngora como final de una canción fúnebre:

... que la mitra y corona, cayado, cetro, espada, es tierra, es polvo, es humo, es sombra, es nada,

sino que lo "mejora": al intercambiar los lugares del humo y el polvo, Melo expresa con mayor nitidez el proceso de desmaterialización de la tierra. ${ }^{25}$

y que resiste al golpe de la muerte, debemos esperar que triunfe de la ignorancia (que "le usurpe sus términos"). De ella debemos esperar que oscurezca la fama del Oráculo de Apolo ("rubio Isleño" porque nació en la isla de Delos) y que supere la victoria de Hércules sobre Anteo, puesto que no existe más valor que la virtud'. En verdad, el verso 14 no viene muy al caso: no ha habido en el soneto ninguna mención de la virtud; pero el recuerdo del verso de Góngora era irresistible.

${ }^{24}$ Quevedo, Obras completas, I, Poesta original, ed. de José Manuel Blecua, Planeta, Barcelona, 1963, pág. 5. Dice Blecua que punto, en el verso 4, significa 'instante', pero yo creo que significa 'punto'. La imagen es geométrica: la vida es como un punto en comparación con la circunferencia (el cerco). Hay sonetos de Quevedo con terminaciones enumerativas: "...cuán frágil es, cuán mísera, cuán vana" (soneto " iCómo de entre mis manos te resbalas!..."), "...pues asco dentro son, tierra y gusanos" (soneto "¿Miras este gigante corpulento?..."). Pero son pocos.

${ }^{25}$ Citado por Alfonso Méndez Plancarte en nota de su edición de Obras completas de Sor Juana, tomo 1 , pág. 519. A ese proceso de "desmaterialización" se refiere seguramente Méndez Plancarte al decir que es "más exacto clímax" el de la canción de Melo que el del soneto de Góngora. 
También Antonio Mira de Mescua rinde homenaje al verso famoso en un pasaje de su auto sacramental Las pruebas de Cristo:

Es el hombre un vil gusano

de las entrañas mas frías

de la tierra, y son sus días

como la flor del verano;

cual sombra del aire vano

huye inconstante, de suerte

que el más bizarro, el más fuerte

es polvo, es rosa pisada,

es viento, es humo yes nada

cuando le traga la Muerte. ${ }^{26}$

Bernardino de Rebolledo, extraño poeta "marginal", que pasó buena parte de su vida en tierras nórdicas como embajador de España, termina así un soneto en que medita sobre su propia muerte ("Este polvo que agitan mar y viento..."):

... que ni temo el morir, ni se me olvida

que vidrio quebradizo y aun quebrado

soy ahora, y seré polvo mañana. ${ }^{27}$

Pero se puede dudar si aquí hay o no verdadero recuerdo del verso de Góngora.

El recuerdo es más perceptible en el verso final de una composición de la longeva (1602-1693) Sor Violante do Céu, o sea "del Cielo", una de las voces femeninas más melodiosas de la literatura portuguesa, "Dézima Musa e Fénix dos engenhos lusitanos":

$$
\text { e tudo o mais é pó, é cinzá, é nada. }
$$

${ }_{26}^{26}$ Citado por Angel Valbuena Prat en Revre Hispanique, 61 (1924), pág. 222.

${ }^{27}$ Ocios del conde don Bernardino de Rebolledo, Amberes, en la Officina Plantiniana, 1660 , soneto LIV.

${ }^{28}$ Citado por Maria de Lourdes Belchior en el Dicionário das literaturas portugue sa, galega e brasileira, Livr. Figueirinhas, Porto, 1960, sub voce "Céu". En un soneto dedicado "A Violante do Ceo, monja en la Rosa de Lisboa" (Fuente de Aganipe, Primera Parte, ed. cit., fol. 100) dice Manuel de Faría y Sousa (con alusión al verso 
Esta contundente máxima - todo lo que no es Dios "es polvo, es ceniza, es nada" - da buen pie para una reflexión. El verso famoso, en el soneto de Góngora, no sólo está al servicio de un mensaje cien por ciento pagano, o sea el Collige, virgo, rosas, sino que inculca estè mensaje con urgencia incomparablemente mayor que el verso final del idilio de Ausonio: 'Goza la vida, gózala hoy mismo. antes que...'. y este antes que anuncia el horror y la nada en que mañana se volverán la belleza y la vida. 'No hay más vida que la que tenemos aquí y ahora': tal es la filosofía subyacente. En cambio, las imitaciones y reformulaciones de ese verso, a partir de Lope de Vega, han estado al servicio de un mensaje cien por ciento cristiano: "sólo Dios agrada", como dice la monja portuguesa; lo demás es "vanidad de vanidades"; esta vida no debe ser sino preparación para la Vida verdadera, la que eternamente vivirá el cristiano contemplando a Dios. $^{29}$ Es como si los muchos imitadores del verso famoso se hubieran propuesto dejar constancia de que en la ultracatólica España del siglo barroco nadie era capaz de aceptar la inmoral moraleja de Ausonio.

El poeta español que mejor encarna ese ascetismo cristiano es sin duda Calderón de la Barca. ${ }^{30}$ Y es notable el número de veces que este gran admirador y divulgador de los primores lingüísticos de

final del soneto de Camoens "Num jardim adornado de verdura..." ) que Apolo quiso a Sor Violante "viola antes que lirio, antes que rosa", pero que ella, "más cuidadosa" que el dios a la hora de escoger, prefirió la rosa, o sea el convento de la Rosa. La idea del juego de palabras procede de Garcilaso (cf. supra, nota 14); pero aquí Faría y Sousa parece emplear viola como sinónimo de violeta ("tú diste al cielo intacta tu violeta", dice otro verso).

29 Isaías, 22:13, condena a quienes dicen "Comamos y bebamos, que manana moriremos"; y San Pablo, al citarlo, añade algo específicamente cristiano, ajeno al Viejo Testamento: "Si los muertos no resucitan, comamos y bebamos...", etc. (I Corintios, 15:32). La base del cristianismo es la fe en la Resurrección y en la Vida eterna. Por eso el Apóstol se duele de que en la comunidad cristiana de Filipos haya todavía algunos "cuyo dios es el vientre" (Filipenses, 3:19): se aferran a lo terreno y viven como cerdos de Epicuro. El famoso Vanitas vanitatum et omnia vanitas con que comienza el Eclesiastés, al incorporarse a la filosofía cristiana, dejó de ser expresión del "pesimismo judio" para convertirse en parte esencial de la fe optimista en la otra Vida. Gracias a esta fe, la idea de que "toda carne es hierba, y toda su gloria como flor del campo", tan repetida en el Viejo Testamento (II Reyes, 19:26; Job, 8:12; Salmos, 36:2, 89:6, 102:15, 128:6; Eclesiástico, 14:18; Isaias, 37:27 y 40:6-8, etc.), tiene otras resonancias cuando reaparece en el Nuevo Testamento (Santiago, 1:10-11; I Pedro, 1:24).

30 Calderón, imitador del idilio de Ausonio en sus sonetos "Estas que fueron 
Antonio Alatorre

Góngora acudió al verso famoso para dar fuerza a su visión de la vida. En 1622, cuando tenía veintidós años, se ganó un premio con un romance sobre la "Penitencia de San Ignacio", que termina así (habla el santo):
...Una llama soy, que vivo, obediente a un fácil soplo, humilde barro, $y$ al fin fuego y humo, tierra y polvo. ${ }^{31}$

Al final de su auto sacramental Los encantos de la Culpa (1649), después de que la Culpa ha tratado de seducir al Hombre con las tentadoras viandas que pone ante sus ojos, aparece "en un carro de triunfo" la Penitencia, afirmando contra su rival el valor supremo de las Virtudes cristianas:

... para que el Hombre vea
que solas a vencer bastan
tus encantos, hoy verás
todas aquestas viandas
del viento desvanecidas
en humo, en polvo y en nada.

En el auto El Año Santo de Roma (1650), el Amor le recuerda al Hombre que la vida terrenal sirve sólo para peregrinar hacia el Cielo,

pompa y alegria..." y "¿Ves esa rosa que tan bella y pura...?", es también uno de los poetas más sordos a su mensaje vital. Del primero de esos sonetos decía Juan de Mairena: Todo [su] encanto-si alguno tiene- estriba en su corrección silogística. La poesía aquí no canta: razona, discurre en torno a unas cuantas definiciones. Es - como todo o casi todo nuestro barroco literario- escolástica rezagada..., pasado abolido, definitivamente muerto" (Antonio Machado, Obras, Ed. Séneca, México, 1940, págs. 391-393). Ya Lope de Vega había cristianizado a Ausonio; en una de sus Rimas sacras (Obras poéticas, ed. Blecua, pág.334) celebra la lección de eternidad que Dios nos da en la rosa: así como ella es efímera, "así las esperanzas son aleves / que tienen en la tierra el fundamento". Tanto más notable es el enfático paganismo de la monja Juana Inés de la Cruz en su soneto "Miró Celia una rosa que en el prado....", donde Celia le dice a la rosa: "Goza, sin temor del hado, / el curso breve de tu edad lozana, / pues no podrá la muerte de mañana / quitarte lo que hubieres hoy gozado."

${ }^{31}$ Romance reproducido por Gallardo, Ensayo, tomo 3, col. 835. 


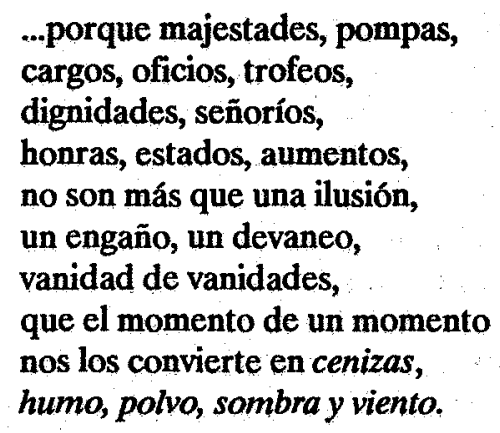

En el auto No hay más fortuna que Dios (1653) se da un paso más: en vez de predicarse como desde un púlpito, el mensaje se escenifica muy meticulosamente. Son indispensables las piezas de utilería que funcionan como símbolos: las capas del Bien y del Mal (que han sido trocadas y luego "destrocadas"), el cetro del Poder, el bastón de la Milicia, la azada de la Labranza y el báculo de la Pobreza; e igualmente indispensable es el escotillón. Vemos así cómo la Hermosura cae en una sima - horroroso bostezo de la tierra", dice gongorinamente Calderón- y cómo van a dar tras ella todos los objetos simbólicos, y cómo, en el momento en que el Bien y el Mal y los cuatro representantes del teatro del mundo intentan meter mano, "a ver qué sacamos", surge de la boca de la sima -"iQué horror! iQué espanto! iQué asombro!"- un Esqueleto, "asido con ambas manos del cetro, azada, bastón y báculo y los dos cabos de las capas", diciendo con voz cavernosa qué es lo que van a sacar: "Humo, polvo, viento y nada". ${ }^{32}$

En la Parte I de El santo rey don Fernando, auto de la vejez (1671), el verso de Góngora resuena mucho más nítidamente, como.final de un soneto. Aquí el contexto es muy distinto. Se trata de un auto "historial", cuyos personajes centrales son el rey Fernando III (representante de la Monarquía española) y Santo Domingo de Guzmán (representante de la Religión). El santo Rey, afligido por el gran número de musulmanes, de judíos y de albigenses que hay en

\footnotetext{
${ }^{32}$ Calderón, Obras completas, ed. de A. Valbuena Prat, tomo 3, Autos sacramentales, Madrid, 1952, págs. 420,496 y 631. Las fechas son las que da el editor. (La de No hay mas fortuna que Dios no es muy segura).
} 
España, se dispone, después de una conversación con el sagaz estudiante Domingo, a fundar la Inquisición. ${ }^{33}$ Se ha quedado solo en la escena para que los espectadores escuchen, sin nada que los distraiga, los versos que gravemente recita:

iOh Señor! Si a tu suma Providencia tal vez rastreara el hombre los motivos y, abiertos de tu seno los archivos, leyera un punto el Libro de tu Ciencia, icon cuánta luz hallara su imprudencia que los decretos más ejecutivos, que a nuestro ver rigores son esquivos, son piedades de oculta conveniencia!

No infausto, pues, te desconsuele el día que ves, ioh España!, en lágrimas bañada, Hebraísmo, Alcorán y Apostasía,

si en Fe, Esperanza y Caridad fundada, pendes de otra, con quien tu monarquía es viento, es polvo, es humo, es sombra, es nada.

Merece un pequeño análisis este soneto. ${ }^{34}$ Los cuartetos se dirigen a Dios y son una profesión de fe ciega en su Providencia: todo lo que nos sucede, aun lo más doloroso, ha sido dispuesto por $\mathrm{El}$, porque $\mathrm{El}$ es el único que sabe lo que nos conviene. Los tercetos se dirigen a España y son una aplicación de esa doctrina. España "pende" del ordenamiento divino (gracias a las tres virtudes teologales): en ella están realizándose, hic et nunc, los designios eternos de Dios; la presencia de judíos, musulmanes y herejes es dolorosa

${ }^{33}$ Es, por supuesto, una "historia" imaginada, o sea poética. Cuando Domingo de Guzmán (1170-1121) era estudiante, no había nacido aún Fernando III (12011252). En el auto de Calderón, el Rey en persona - tal es el santo celo que lo animaacarrea leña para la hoguera en que morirá la herejía albigense (llamada Apostasía). La Inquisición se créó en efecto para reprimir a los albigenses, pero fue idea de los papas, no de los reyes de España. Por lo demás, en Castilla y León no hubo albigenses. (Calderón los presenta como negadores de la transubstanciación y de la inmortalidad del alma, y coligados con los judíos).

${ }^{-34}$ Calderón, ed. cit., págs. 1278-1279. (He corregido la puntuación en varios lugares). 
en grado sumo, pero he aquí que viene el consuelo. (Los contemporáneos de Calderón, espectadores de su auto, saben muy bien que España, desde tiempos de Felipe II, ha dejado de estar "en lágrimas bañada", gracias a los buenos oficios de la Inquisición. La triple calamidad, "Hebraísmo, Alcorán y Apostasía", no es ya sino una orla en el gran tapiz de los piadosos designios de Dios). Lo que encuentro más notable en este notable soneto es la función del verso final. No creo que Calderón se haya propuesto rebajar tan excesivamente a la monarquía española. ${ }^{35}$ Lo que creo es que quiso rematar un soneto muy solemne de la manera más solemne posible, y además con un efecto de sorpresa. Esperábamos oír: 'Tú, España, tienes una monarquía que pende de otra, la suprema, la divina; tus monarcas tienen, pues, algo de divino; ellos saben lo que te conviene; confía en ellos..., etc. Pero lo que oímos es: 'La monarquía española, lo más grande que hay en el mundo, ies nada!...'

El amor especial que Calderón tuvo por el verso de Góngora debió haber influido en sus contemporáneos y en sus sucesores inmediatos. Dos de ellos, José Delitala y José Pérez de Montoro, lo emplearon en composiciones fúnebres (como habían hecho Faría y Sousa y Francisco Manuel de Melo). Delitala lo pone como remate de un madrigal "A la Marquesa de Pobar, muerta en sus floridos años". "Habla el mármol" de la lápida para decir cuán brevemente lució en el mundo

$$
\begin{aligned}
& \text { aquella prenda cara } \\
& \text { del volador Cupido } \\
& \text { y ya es ceniza, sueño, sombra, olvido. }
\end{aligned}
$$

Pérez de Montoro, gran elogiador de Sor Juana, retoma en su soneto a la muerte de la Marquesa del Carpio los cinco elementos del verso gongorino, poniéndolos no sólo al final, sino también en los cuartetos; en esquema distributivo:

\footnotetext{
${ }^{35}$ Podría interpretarse este verso como expresión de la humildad del santo Rey, pero no vendría aquí muy al caso. También podría pensarse que los "decretos ejecutivos" (o sea 'inexorables') y los "rigores esquivos" (o sea 'salvajes') del segundo cuarteto aluden a las torturas y hogueras inquisitoriales, pero sería imaginar a un Calderón capaz de condolerse de las víctimas, de ponerse en su pellejo, lo cual no puede ser (no sin motivo se le ha llamado "el poeta de la Inquisición").

${ }^{36}$ Joseph Delitala y Castelvi, Cima del monte Pamaso español, con las tres Musas castellanas Caliope, Urania y Euterpe, Cáller [Cagliari, Cerdeña], 1672, pág. 399. (Esta Cima pretende ser remate o culminación del Parnaso de Quevedo).
} 
iTierra no más el cielo de Medina! iCasi polvo la fábrica más bella! iHumo apenas la más viva centella, y aun sombra ya la luz más peregrina!

iNada! iNada! Mas. idónde se encamina impaciente el dolor con la querella de la nada que ve, si ya es en ella fe humana la esperanza de divina?

Señas su muerte dio que arguyen gloria; luego en ésta, de todos envidiada por piedad, por razón se ha de hallar modo

de trocar sabiamente la memoria, la tierra, polvo, humo, sombra y nada, en cielo, en lluvia, en luz, en aire y todo. ${ }^{37}$

Se habrá notado cómo algunos de los elementos del verso gongorino han sido sustituidos por otros en las imitaciones: vidrio, ceniza, barro, lodo, rosa pisada, punto, viento, sueño, olvido. El soneto que a Sor Juana le inspiró la contemplación de su retrato ("Este que ves, engaño colorido...") acumula nuevos sinónimos en los tercetos: afán caduco, flor al viento, etc., y en la enumeración final sustituye la tierra y el humo por algo más preciso y de sonido más terrible:

... es un vano artificio del cuidado, es una flor al viento delicada, es un resguardo inútil para el hado,

es una necia diligencia errada, es un afán caduco y, bien mirado, es cadáver, es polvo, es sombra, es nada.

\footnotetext{
${ }^{37}$ Joseph Pérez de Montoro, Obras póstumas hyricas humanas [y divinas], Madrid, 1736, tomo 1, pág. 3. Otro de sus sonetos fúnebres (ibid., pág. 8) termina así: ",..y si es menos que sombra, voy tras ella, / y aun siendo sombra de la misma sombra". Pérez de Montoro (1627-1694) estaba al servicio de los Duques de Medinaceli, familia a la cual pertenecía la Marquesa del Carpio (en el primer verso del soneto citado en el texto, "cielode Medina" es Medinaceli). A esa misma familia pertenecía el Marqués de la Laguna, el virrey protector de Sor Juana.

${ }^{38}$ En su traducción de este soneto (publicada en el revista Vuelta, núm.146, enero đe 1989, pág. 68), Katherine Ann Porter tuvo que extender el último verso en un alejandrino: "...a perishable thing: and clearly seen / it is a corpse, a whirl of dust, a shadow, -nothing".
} 
Jerónimo Monforte y Vera, que contribuyó a la Fama pósthuma de Sor Juana (1700) con una "Elegía" (hecha en el metro que Sor Juana llamó "ovillejos"), y que más tarde se trasladó de España al Perú, donde fue miembro de la academia limeña presidida por el virrey Marqués de Castell-dos-Ríus, escribió en el "acta fúnebre" de la academia (1713), al disolverse por muerte del virrey, esta octava de esquema distributivo-recapitulativo:

Es la vida trofeo de la muerte de que no se exceptúa la grandeza. Aire es la fantasía de la suerte, polvo es la perfección de la belleza, humo es la vanidad de horror se advierte, y nada es el valor de la riqueza.

¿Qué fías, pues, oh alma enajenada, en lo que es aire, es polvo, es humo, es nada? ${ }^{39}$

También el novohispano Francisco Ruiz de León puso el verso famoso al final de una octava:

Mundo inconstante, ¿dónde tu ventura [...], si fausto, honor, soberanía, grandeza conviertes, a un impulso de tu azada, en tierra, en lodo, en polvo, en humo, en nada? ${ }^{40}$

Eugenio Gerardo Lobo (1679-1750) lo puso como verso final de un soneto fúnebre, "No suspendas el paso, caminante...":

...Hallarás con congoja dilatada honor, riqueza, calidad y vida en polvo, en humo, en ilusión, en nada. ${ }^{41}$

\footnotetext{
${ }^{39}$ Flor de Academias y Diente del Pamaso, ed. de Ricardo Palma, Lima, 1899, pág. 328.

${ }^{40}$ Francisco Ruiz de León, Hernandia, Madrid, 1755, canto X, octava 48. Citado por Méndez Plancarte, Obras completas de Sor Juana, tomo 1, pág.519.

${ }^{41}$ Eugenio Gerardo Lobo, Obras poéticas, ed. de Madrid, 1758, pág. 10. Es el segundo de una serie de tres sonetos a la muerte del Duque de Osuna, coronel del regimiento de Guardias. (Lobo era militar de carrrera.)
} 
También lo empleó Diego de Torres Villarroel (1693-1770) en otro soneto fúnebre, pero él lo puso al comienzo (como ya había hecho Pérez de Montalbán):

La tierra, el polvo, el humo, en fin, la nada del héroe más plausible y portentoso... ${ }^{42}$

Seguramente se me escapan otros ecos, pues no suelo leer a los poetas del siglo XVIII, como tampoco -salvo contadas excepciones- a los del XIX. El único eco claro que he hallado está en un "Soneto hecho en el Miércoles de Ceniza del año de 1811" por José Joaquín Fernández de Lizardi: "¿Ya ves del rey el cetro dominante...?" Es plenamente barroco, con esquema distributivo-recapitulativo, y su inspiración es muy calderoniana. Desfilan el cetro, la instrucción, el acero (la espada militar), el afán (de dinero) y la belleza. La ceremonia del Miércoles de Ceniza -"Memento, homo, quia pulvis es ..."-nos recuerda que todo eso es vanidad, y que

... es en la muerte, al fín de la jornada, cetro, instrucción, acero, afán, belleza, polvo, sombra, ceniza, viento y nada. ${ }^{43}$

En el siglo XIX no se leyó a Góngora, ni a Calderón, ni a Sor Juana. Si alguien, mejor enterado que yo, encuentra aquí o allá algún eco del verso famoso, será probablemente como éste que creo percibir en el final del soneto "Al Sol" de Rafael María Baralt (1810-1860), respuesta a la pregunta "¿Quién la lumbre te da? ¿Quién los ardores...?":

...El Ser a quien tu luz, que nos asombra, es fuego sin calor, es mancha, es sombra. ${ }^{44}$

\footnotetext{
${ }^{42}$ Diego de Torres Villarroel, Juguetes de Talia, tomo 8 de sus Obras, Madrid, 1795, pág. 94. El "héroe" cuya muerte se deplora es un Conde de Monterrey.

${ }^{43}$ José Joaquín Fernández de Lizardi, Obras, I, Poestas y fabulas, ed. de Jacobo Chencinsky y Luis Mario Schneider, México, 1963, pág. 94.

${ }^{44}$ Biblioteca de Autores Españoles, tomo 204, pág. 10. Emilio Carilla, El gongorismo en América, Buenos Aires, 1946, pág: 215, observa que a comienzos del siglo XIX hay en los países hispanoamericanos una "muy vaga persistencia" de Góngora, y que los versos románticos nos muestran "su desaparición completa". Las únicas
} 
Pero no puede afirmarse que Góngora haya sido el inspirador de este final. Versos así, como remate de un poema, son de todos los tiempos y de todos los lugares. Se me ocurren tres ejemplos. El primero es un soneto de Francisco de Figueroa (poeta de la generación de fray Luis de León, ajeno a la influencia de Góngora), cuyo final dice:

... que ya del alma, el árbol de vitoria que plantó Amor, cortaron desengaños, desdén, ausencia, tiempo, edad, mudanza. ${ }^{45}$

El segundo es un poema de Miguel de Unamuno, "¿Qué es tu vida, alma mía...?", cuyo verso final seguramente no tiene nada de Góngora, pero cuyo esquema es distributivo-recapitulativo (cosa rara en la poesía moderna). Después de decir dos veces "lluvia en el lago", "viento en la cumbre" y "sombra en la cueva", termina así:

... Lágrimas es la lluvia desde el cielo, y es el viento sollozo sin partida, pesar la sombra sin ningún consuelo, y lluvia y viento y sombra hacen la vida. ${ }^{46}$

Y el tercero es un melancólico poema del inglés Philip Larkin (muerto en 1985). El poeta pasea en bicicleta por el campo y se detiene a ver una iglesita rural donde ya no hay culto porque la gente ya no cree; lo único que queda es algo de superstición,

... But superstition, like belief, must die, And what remains when disbelief has gone? Grass, weedy pavement, brambles, buttress, sky ... ${ }^{47}$

excepciones que encuentra son un colombiano, José Joaquín Ortiz, y dos venezolanos, Andrés Bello y Rafael María Baralt, "hecho paradojico" -dice-, pues en Venezuela casi no hubo gongorismo "durante el coloniaje". Al estudiar las reminiscencias gongorinas de Baralt (págs. 217-218) no menciona el soneto "Al Sol".

${ }^{45}$ Francisco de Figueroa, Obras, Lisboa, 1626, pág. 26. Cf. también supra, nota 16, el verso de fray Luis "y noche $y$ amargor y llanto y muerte"

${ }^{46}$ Miguel de Unamuno, Romancero del destierro (1928). Véase D. Alonso y C. Bousoño, Seis calas... op. cit, págs. 80-81.

${ }^{47}$ Philip Larkin, "Church Going", en su libro The Less Deceived, Londres, 1955. (Este poema merecería una traducción más convincente que la que publicó Jorge Ruiz Esparza en Vuelta, núm. 122, enero de 1987, pág. 15.) 
Esta sensación de melancolía y de vacío es la que deja el último verso de "La serie sustantiva" del modernista Guillermo Valencia, soneto así llamado por estar hecho todo de sustantivos:

Cuna. Babero. Escuela. Libros. Tesis. Diploma. Pobreza. Pleitos. Jueces. Aulas. Corte. Ruido. Comités. Elecciones. Tribuna. Gloria. Olvido. Viajes. Molanga. El bosque. Londres, París o Roma. Regreso. Novia. Enlace. Rorros. Dientes. Aroma. Ilusión. Señoritas. La sociedad. Marido.

Bailes. Celos. Pesares. Esclavitud. Gemido. Nietos. Babero. Escuelas. Griego, Latín y Doma. Vejez. Gota. Desvelos. Desilusión. Novenas. Calva. Ceguera. Gripe. Vértigos. Callos. Penas. Abandono. Esquiveces. El patatús. La fosa.

Llanto. Duelo. Discursos. Decreto. Paz. Sonrisa. Risa. Chales. Pianola. Paseos. Una misa. Tumba. Silencio. Ortigas. Ausencia. Cruz mohosa. ${ }^{48}$

Miguel Hernández fue ciertamente lector de Góngora, de manera que es muy posible que recordara su famoso verso al final de "Sino sangriento" ("De sangre en sangre vengo / como el mar de ola en ola...", en Otros poemas):

... Me dejaré arrastrar hecho pedazos, ya que así se lo ordenan a mi vida la sangre y su marea, los cuerpos y mi estrella ensangrentada. Seré una sola y dilatada herida hasta que dilatadamente sea un cadáver de espuma: viento y nada.

Y lo mismo digo del final del burlón soneto XIV de Homero en Cuemavaca ("Paris gandul..."), pues Alfonso Reyes fue no sólo lector, sino estudioso de Góngora:

\footnotetext{
${ }^{48}$ Guillermo Valencia, Obras poéticas completas, Madrid, 1948, pág. 538.
} 
... Muchos hay como tú que obran portentos a la hora del baño y los ungüentos, y al combatir son aire y humo y vaho.

Bastante más audible es el eco de Góngora en el final de "El alquimista" de Borges (en El otro, el mismo):

... Y mientras cree tocar enardecido el oro aquel que matará la Muerte, Dios, que sabe de alquimia, lo convierte en polvo, en nadie, en nada y en olvido.

Enumeraciones como ésa son frecuentes en Borges. He aquí un ejemplo ("El hacedor", en La cifra):

... Pesadas campanadas del insomnio, auroras y ponientes y crepúsculos, ecos, resaca, arena, liquen, sueños...

En el desengañado y melancólico Angel González los ecos de Góngora están más apagados. Así en unos versos de su "Mensaje a las estatuas" (en Sin esperanza, con convencimiento); ha dicho que el tiempo es más tenaz que las inmóviles y arrogantes estatuas, y que también a ellas las espera la tierra:

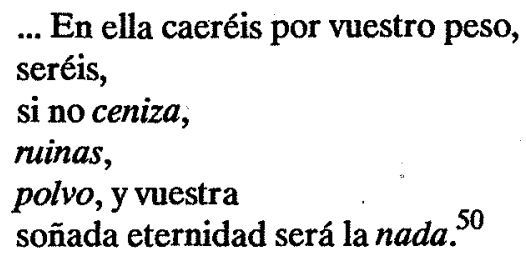

\footnotetext{
${ }^{49}$ Más ejemplos de Elotro, el mismo: "...miro este querido / mundo que se deforma y que se apaga / en una pálida ceniza vaga / que se parece al sueño y al olvido" (el don de la ceguera, en el "Poema de los dones"); "...¿Qué dios detrás de Dios la trama empieza / de polvo y tiempo y sueño y agonia?" ("Ajedrez, II"); "Aire, agua, pan, mañanas, piedra y lirio, / pero después la sangre del martirio, / el escarnio, los clavos y el madero" ("Juan, 1, 14").

${ }^{50} \mathrm{Cf}$. también este poema de Breves acotaciones para una biografla: "Meriendo algunas tardes / [...] y cuando se me acaban / me voy rumiando sombras, / rememorando el tiempo devorado / con un acre sabor a nada en la garganta".
} 
El eco de Góngora es más claro en el "Canto de Francesca" de la puertorriqueña Rosario Ferré (Fábulas de la garza desangrada):

... lo amó, no hay por qué dudarlo [...],

descuajó en su nombre el antes del después, el siempre, el sangre, el sombra, el polvo, el nada...

Sirva de punto final el poemita "Mañana" del regiomontano Ramiro Garza, ${ }^{51}$ que perfectamente puede aplicarse al presente artículo:

Este escribir, Dios mío...

iQué vanidad tan breve y propagada! [...]

Total, mañana somos

(con todo y escribir)

tierra,

recuerdos,

nada.

${ }^{51}$ Diecinueve poetas contempordneos de Nuevo León, ed. de Jorge Cantú de la Garza y Humberto Salazar, Monterrey, 1989, pág. 24. 